\title{
Evaluation of Microbial Consortium for the Rapid Composting of Urban Solid Waste
}

\author{
Davalsab Javoor* and B. Narayanaswamy \\ Department of Agricultural Microbiology, College of Agriculture, UAS, GKVK, \\ Bengaluru-560 065, India \\ *Corresponding author
}

\section{A B S T R A C T}

\section{Keywords \\ Urban solid waste, degradation, microbial consortium, enzyme production, $\mathrm{C} / \mathrm{N}$ ratio}

Article Info

Accepted: 12 March 2021 Available Online: 10 April 2021
An investigation was carried out to screen the efficient urban solid waste degrading microorganisms for the formulation of microbial consortium. During the process of degradation, bacterial population was dominated over fungal and actinobacteria. The succession of microorganisms during degradation process showed bacterial population $\left(58 \times 10^{6} \mathrm{cfu} / \mathrm{g}\right)$ was found highest compared to fungal population $\left(39 \times 10^{3} \mathrm{cfu} / \mathrm{g}\right)$ and actinobacterial $\left(24 \times 10^{3} \mathrm{cfu} / \mathrm{g}\right)$ population. Totally fifty five bacterial, thirty two fungal and seven actinobacterial strains were isolated during sixty days of urban solid waste incubation. All the bacterial isolates were found rod shaped and non-endospore formers. Among the bacterial isolates, UWCB-16, UWCB-29 and UWCB-34 were Gram positive. All the isolated organisms showed positive for the cellulase, pectinase, protease, amylase, ligninase and chitinase production. Fungal isolate UWCF-07 $(27 \mathrm{~mm})$ showed highest zone followed by the bacterial isolate UWCB-25 $(26 \mathrm{~mm})$ for cellulase production. Bacterial isolate UWCB-34 $(26 \mathrm{~mm})$ recorded highest pectinase producing ability followed by fungal isolate UWCF-07 $(24 \mathrm{~mm})$, where as protease and amylase production was found in the bacterial isolates UWCB-34 (23 $\mathrm{mm})$ and UWCB-25 $(20 \mathrm{~mm})$ respectively. Ligninase production ability was highest in fungal isolates. Fungal isolate UWCF-09 and 07 (107.91 and 106.48) showed significant reduction in the $\mathrm{C}: \mathrm{N}$ followed by actinobacterial isolate UWCA-05 (111.72) and bacterial isolate UWCB-25 (114.18) during decomposition of saw dust with urban solid waste. Among twelve microbial cultures screened, six cultures were selected to form the consortium based on their ability to produce enzymes, carbon and nitrogen mineralization efficiency, which includes three fungi (Trichoderma harzianum (UWCF-09), Penicillium polonicum (UWCF-07) and Coprinus sp. (UWCF-02)), two bacteria (Bacillus cereus (UWCB-34), Bacillus licheniformis (UWCB-25)) and an actinobacteria (Streptomyces albus (UWCA-05)) respectively. 


\section{Introduction}

Residents in all major Indian cities among others have been protesting against unscientific dumping of solid waste, but the fact that $70 \%$ of all the garbage generated continues to be unscientifically disposed off every day is no good news. Data accessed from the Central Pollution Control Board (CPCB), based on reports of various state boards, show the total quantity of municipal solid waste (MSW) generated only from cities and towns in the country i.e., 1,42,870 (1.43 lakh) tonnes per day, and $9 \%$ (12,858 tonnes) of it is not even collected. Bengaluru now generates about 3,700 tonnes of solid waste per day and only $50 \%$ of the waste is segregated (Chethan Kumar, 2017).

One of the biggest challenges in front of the modern society is the proper handling and management of the solid waste being produced indiscriminately. Per capita of waste generating per day ranges from 0.36 to 0.43 kg/ capita/ day (Joshi and Ahamed, 2016). Almost all of the collected wastes are disposed in the open dumps. This requires the acquiring of the more land as dump sites and landfill sites, which is likely to dwindle in the future due to increase in population which has touched the 7 billion mark worldwide due to requirements for residential agriculture and industrial purposes. The projected land requirement for India to dispose MSW in 2047 would be about $1,400 \mathrm{~km}^{2}$ against the present land requirement of $100 \mathrm{~km}^{2}$. In this scenario, it is important to look for alternative technologies which could be utilized for easy and faster management of the solid waste in the available space. The non-biodegradable fraction of solid wastes could be sent for recycling, while the biodegradable fraction could be converted into useful organic manure or compost. Recovery of wastes in the form of energy could be done through incineration or by conversion into refuse derived fuels or by pelletization (Soud, 2013). In any solid waste management system, the functional elements are to be taken care in a proper way. Usually the six main functional elements from the point of generation to final disposal are: (1) waste generation; (2) waste handling and separation; (3) collection; (4) separation and processing and transformation of solid wastes; (5) transfer and transport and (6) disposal (Heckman, 2006).

The total nitrogen, $\mathrm{P}_{2} \mathrm{O}_{5}$ and $\mathrm{K}_{2} \mathrm{O}$ content of this work out to be 2.5 lakh tonnes of $\mathrm{K}_{2} \mathrm{O}$ with a $\mathrm{C} / \mathrm{N}$ ratio of 21 to 31 . This is almost equivalent to 5.4 tonnes of urea, 6.12 lakh tonnes of super phosphate and 4.3 lakh tonnes of muriate of potash (MOP) (Channabasavanna and Rahaman, 2002). Rapid industrialization and population explosion in India has led to the migration of the people from villages to cities, which generates thousands of tonnes of MSW daily. The MSW is expected to increase significantly in the near future as the country strives to attain an industrialized nation status by the year 2020 (Sharma and Shah, 2005). Keeping the above points in view, the present study was undertaken for isolation, screening and characterization of efficient microorganisms for urban solid waste decomposition, and formulation of microbial consortium and their evaluation for rapid composting of the urban solid waste was conducted in the Department of Agricultural Microbiology, University of Agricultural Sciences, GKVK, Bengaluru-65.

\section{Materials and Methods}

\section{Collection of samples}

Urban solid waste sample collected from BBMP, Byatarayanapura, Karnataka. Ten kilogram of sample was kept for degradation for 60 days duration in four replications. Optimum moisture and turning was ensured during the process of degradation. During the 
incubation, samples were drawn at different intervals (initial, $7^{\text {th }}, 15^{\text {th }}, 30^{\text {th }}, 45^{\text {th }}$ and $60^{\text {th }}$ days after incubation) and subjected for studying general groups of microorganisms i.e. bacteria, fungi and actinobacteria and functional diversity of microorganisms associated with urban solid waste degradation.

\section{Isolation of urban solid waste degrading microorganisms}

Standard serial dilution plate count technique was adopted for the enumeration and isolation of bacteria, fungi and actinobacteria using spread plate method. Nutrient agar was used for the enumeration of bacteria, Kuster's agar for actinobacteria and Rose Bengal Agar for fungi. $0.1 \mathrm{ml}$ of $10^{3}$ dilution was used for the isolation of fungi and actinobacteria, whereas $10^{6}$ dilution for bacteria. The agar plates were incubated in an inverted position at $37^{\circ} \mathrm{C}$ in an incubator. Two days incubation was given for bacterial isolates, one week incubation for fungal isolates and ten days incubation for actinobacteria. Totally fifty five bacteria, thirty two fungal and seven actinobacterial isolates were isolated; further these isolates were preserved on agar slants for further use.

\section{Morphological and biochemical characterization of microorganisms}

The microbial colonies from the plates were purified by subculturing them to new plates containing the respective media for bacteria, fungi and actinobacteria. The bacterial colonies were screened for the colony morphology and microscopic analysis as per the standard procedures given by Anonymous (1957) and Barthalomew and Mittewer (1950) respectively. All the bacterial isolates were biochemically characterized by evaluating IMViC, catalase, urease and $\mathrm{H}_{2} \mathrm{~S}$ production ability of the isolates were essentially carried out as per the standard procedures outlined by Cappuccino and Sherman (1992).
Screening the isolates for enzyme production

For testing protease production ability, the isolates were streaked on skim milk agar medium. The clear zones around the colony against a black background after incubation were taken as positive. The clear zone around the microbial growth when flooded with Lugol's Iodine was taken as the hydrolysis of starch done by the amylase enzyme. The appearance of clear zone around the colony showed the production of cellulase enzyme when colonies grown on cellulose agar medium were stained with 0.1 per cent Congo red solution for 10 minutes and then destained with $1 \mathrm{M} \mathrm{NaCl}$ solution for half an hour. Pectinase enzyme production was analyzed on Hankin's agar medium containing pectin by staining with one per cent aqueous solution of hexadecyl trimethyl ammonium bromide for 10 minutes. A clear zone around the colonies was considered as positive for pectinolytic activity. Microorganisms capable of degrading chitin were tested on nutrient agar medium supplemented with $2 \%$ colloidal chitin powder, then agar plates are stained with iodine solution and left for 20 minutes. A clear zone around the colonies were considered as positive for chitinolytic activity. The clear zone around the colony when flooded with iodine solution on lignin basal medium (LBM) supplemented with $0.25 \%$ $\mathrm{w} / \mathrm{v}$ lignin, $1.6 \% \mathrm{w} / \mathrm{v}$ agar and $20 \% \mathrm{w} / \mathrm{v}$ aqueous glucose solution was considered as positive for the ligninase production. Totally twelve efficient isolates including bacteria, fungi and actinobacteria, each four isolates, were selected based on the enzyme production ability.

\section{Carbon and nitrogen mineralization of the selected isolates}

The twelve efficient microbial isolates selected were further screened for testing the efficiency in enhancing the speed of 
composting. These isolates were individually inoculated to the beaker containing urban solid waste with sawdust in 2:1 ratio for 30 days duration to test for carbon and nitrogen mineralization efficiency with four replications.

Optimum moisture was maintained with regular turnings. The samples were drawn at initial, $10^{\text {th }}, 20^{\text {th }}$ and $30^{\text {th }}$ days after degradation. Further, the organic carbon (OC) content was determined by using Walkley and Black's (1934) method, and total nitrogen (N) was estimated by using the Micro Kjeldahl method as outlined by Piper (1966) using Automatic Kjeldahl set.

\section{Selection of microorganisms for formulation of consortium}

Out of the twelve efficient isolates used during carbon and nitrogen mineralization, six isolates including two bacterial, three fungal and an actinobacterial isolates, which are nonantagonistic against each other, were selected for testing their suitability for preparing the consortium of microorganisms to be used for enhancing the rate of degradation. The selection was based on the efficiency of the isolate to produce specific enzymes, carbon and nitrogen mineralization which are having definite role in biodegradation for enhancing the rate of degradation of urban solid waste.

\section{Molecular identification of selected microbial isolates}

The efficient isolates for development of consortium comprised of bacterial and actinobacterial isolates characterized by partial sequencing of $16 \mathrm{~S}$ rRNA and fungal isolates characterized with partial 18S rRNA, 5.8S rRNA gene sequencing of internal transcribed spacer 1 (ITS1) and internal transcribed spacer 4 (ITS4).

\section{Results and Discussion}

Succession of microorganisms during urban solid waste degradation

The results obtained on the mean number of colony forming units of bacteria, fungi and actinobacterial isolated at different days of urban solid waste degradation is presented in the Table 1. Among the microbial groups isolated, the bacterial colonies were dominated compared to fungi and actinobacteria throughout the period of urban solid waste degradation.

During initial days of degradation, fungi and actinobacteria colonies were found less, but the activity of fungi and actinobacteria were found during $7^{\text {th }}$ and $15^{\text {th }}$ days respectively after degradation of urban solid waste. Bacterial population $\left(58 \times 10^{6} \mathrm{cfu} / \mathrm{g}\right)$ was highest during $30^{\text {th }}$ day of degradation, whereas the population of fungi $\left(39 \times 10^{3} \mathrm{cfu} /\right.$ g) was highest during $45^{\text {th }}$ day of degradation. During $60^{\text {th }}$ day of urban solid waste degradation, population of actinobacteria $\left(21 \times 10^{3} \mathrm{cfu} / \mathrm{g}\right)$ was highest compared to population of bacteria and fungi. This might be due to the temperature variation during degradation.

Macdonald and Griffin (1981) noted that the composting process is brought about by several organisms such as bacteria, fungi, actinobacteria and protozoa and may also involve invertebrates such as nematodes, potworms, earthworms, mites and various other organisms. Usually aerobic composting process proceeds through a succession of microbial population beginning with mesophilic microorganisms. So the release of temperature through microbial respiration favours the suppression of mesophilic microorganisms as well as the growth and multiplication of thermophilic microorganisms (Tiquia and Tam, 2000). 


\section{Morphological and biochemical} characterization of bacterial isolates

The identical cultures from the same source of urban solid waste compost during degradation were eliminated by selecting only representative isolates from identical colonies having the same morphological characterization. Among bacterial isolates i.e., UWCB-16, UWCB-25, UWCB-29 and UWCB-34 subjected for biochemical characterization. All the four bacterial isolates were rod shaped and non-endospore formers. Three bacterial isolates showed positive for Gram's reaction except the isolate UWCB-25.

Most of the isolates were circular, mucoid and medium colony formers on the nutrient agar plates with pink, brown and white to dense white pigmentation. All the four bacterial isolates showed negative for Indole and $\mathrm{H}_{2} \mathrm{~S}$ production tests. UWCB-34 showed positive for Vogue's proskeur, citrate utilization, catalase and urease tests, whereas other bacterial isolates were performed negative for almost all biochemical tests conducted. These results are in conformity with the study of Saha et al., (2014) where they have isolated nine bacterial cultures from the waste dump sites of Dhapa and Barrackpore Municipality Area. Out of the nine isolates, five isolates were having rod shaped cells, four isolates were Gram negative and one was endospore producer, and were positive for oxidase, catalase and methyl red test. Zaved et al., (2018) also isolated Bacillus sp. and Pseudomonas sp. belonged to Gram negative bacteria having rod shaped cell from (NAIUL and BC Dump) Kushtia and Jhenaidha regions of Bangladesh.

Screening of efficient urban solid waste degrading microorganisms

Efficiency of the selected bacterial, fungal and actinobacterial isolates were screened in the laboratory by plate assay for enzyme production. The zone $(\mathrm{mm})$ produced by all the bacterial, fungal and actinobacterial isolates are in Table 3. Majority of the isolated organisms showed positive for the production six enzymes which were statistically significant. Among the three groups of isolated organisms, fungal isolates UWCF-07 $(27 \mathrm{~mm})$ and UWCF-09 (24 mm) showed highest zone diameter followed by bacterial isolates UWCB-25 $(26 \mathrm{~mm})$ and UWCB-34 $(25 \mathrm{~mm})$ for cellulase production.

Table.1 Succession of microorganisms during urban solid waste degradation.

\begin{tabular}{|c|c|c|c|}
\hline \multirow[t]{2}{*}{ Days of degradation } & \multicolumn{3}{|c|}{ Population of microorganisms } \\
\hline & $\begin{array}{c}\text { Bacteria } \\
\left(\text { CFU } \times 10^{6} / g\right)\end{array}$ & $\begin{array}{c}\text { Fungi } \\
\left(\mathbf{C F U} \times 10^{3} / \mathrm{g}\right)\end{array}$ & $\begin{array}{l}\text { Actinobacteria } \\
\left(\text { CFU } \times 10^{3} / g\right)\end{array}$ \\
\hline Initial & 08 & 03 & 02 \\
\hline 15 & 41 & 31 & 10 \\
\hline 30 & 58 & 26 & 13 \\
\hline 45 & 49 & 39 & 24 \\
\hline 60 & 18 & 19 & 21 \\
\hline 75 & 10 & 5 & 24 \\
\hline 90 & 6 & 3 & 23 \\
\hline
\end{tabular}


Table.2 Morphological and biochemical characterization of bacterial isolates during urban solid waste degradation

\begin{tabular}{|c|c|c|c|c|c|c|c|c|c|c|c|}
\hline Isolates & $\begin{array}{c}\text { Colony } \\
\text { morphology }\end{array}$ & $\begin{array}{l}\text { Gram's } \\
\text { reaction }\end{array}$ & $\begin{array}{c}\text { Bacte } \\
\text { rial } \\
\text { shape }\end{array}$ & $\begin{array}{l}\text { Endospore } \\
\text { formation }\end{array}$ & $\begin{array}{c}\text { Indole } \\
\text { test }\end{array}$ & $\begin{array}{l}\text { Methyl } \\
\text { red } \\
\text { test }\end{array}$ & $\begin{array}{l}\text { Voges } \\
\text { proskau } \\
\text { er test }\end{array}$ & $\begin{array}{c}\text { Citrate } \\
\text { utilizatio } \\
\text { n } \\
\text { test }\end{array}$ & $\begin{array}{l}\text { Catalas } \\
\text { e test }\end{array}$ & $\begin{array}{c}\text { Urease } \\
\text { test }\end{array}$ & $\begin{array}{c}\mathrm{H}_{2} \mathrm{~S} \\
\text { Production } \\
\text { test }\end{array}$ \\
\hline $\begin{array}{c}\text { UWCB- } \\
16\end{array}$ & $\begin{array}{l}\text { Orange oval } \\
\text { medium size }\end{array}$ & + & Rod & - & - & + & - & - & + & - & - \\
\hline $\begin{array}{c}\text { UWCB- } \\
25\end{array}$ & $\begin{array}{l}\text { Whitish, } \\
\text { mucoid, } \\
\text { medium size }\end{array}$ & - & Rod & - & - & - & + & + & - & - & - \\
\hline $\begin{array}{c}\text { UWCB- } \\
29\end{array}$ & $\begin{array}{l}\text { Brown, circular, } \\
\text { medium size }\end{array}$ & + & Rod & - & - & - & + & + & + & + & - \\
\hline $\begin{array}{c}\text { UWCB- } \\
34\end{array}$ & $\begin{array}{l}\text { Milky, large, } \\
\text { convex, opaque, } \\
\text { dry colonies }\end{array}$ & + & Rod & - & - & - & + & + & + & + & - \\
\hline
\end{tabular}


Table.3 Screening of efficient urban solid waste degrading microorganisms for enzyme production

\begin{tabular}{|c|c|c|c|c|c|c|}
\hline \multirow[t]{2}{*}{ Isolates } & \multicolumn{6}{|c|}{ Zone diameter $(\mathrm{mm})$} \\
\hline & Cellulase & Pectinase & Protease & $\begin{array}{c}\text { Starch } \\
\text { hydrolysis }\end{array}$ & $\begin{array}{c}\text { Lignolytic } \\
\text { Enzyme }\end{array}$ & Chitinase \\
\hline UWCB-16 & $23^{\text {cde }}$ & $19^{\mathrm{de}}$ & $18^{\mathrm{ab}}$ & $19^{\mathrm{abc}}$ & $08^{\mathrm{d}}$ & $16^{c}$ \\
\hline UWCB-25 & $26^{a b}$ & $21^{\mathrm{cd}}$ & $20^{\mathrm{a}}$ & $20^{\mathrm{ab}}$ & $18^{\mathrm{ab}}$ & $19^{\mathrm{a}}$ \\
\hline UWCB-29 & $22^{b}$ & $20^{\text {cde }}$ & $15^{\mathrm{abc}}$ & $18^{\mathrm{bcd}}$ & $08^{\mathrm{d}}$ & $13^{\mathrm{bcd}}$ \\
\hline UWCB-34 & $25^{\mathrm{abc}}$ & $26^{\mathrm{a}}$ & $19^{\mathrm{a}}$ & $23^{\mathrm{a}}$ & $18^{\mathrm{ab}}$ & $17^{\mathrm{ab}}$ \\
\hline UWCF-02 & $21^{\mathrm{ef}}$ & $19^{\mathrm{de}}$ & $10^{\mathrm{cd}}$ & $15^{\mathrm{cd}}$ & $22^{a}$ & $13^{\text {bcd }}$ \\
\hline UWCF-06 & $20^{\mathrm{fg}}$ & $16^{\mathrm{f}}$ & $08^{\mathrm{d}}$ & $14^{\mathrm{d}}$ & $16^{\mathrm{bc}}$ & $10^{\mathrm{d}}$ \\
\hline UWCF-07 & $27^{\mathrm{a}}$ & $24^{\mathrm{ab}}$ & $15^{\mathrm{abc}}$ & $15^{\mathrm{cd}}$ & $22^{\mathrm{a}}$ & $14^{\mathrm{bcd}}$ \\
\hline UWCF-09 & $24^{\mathrm{bcd}}$ & $22^{\mathrm{bc}}$ & $13^{\text {bcd }}$ & $15^{\mathrm{cd}}$ & $22^{a}$ & $13^{\text {bcd }}$ \\
\hline UWCA-03 & $15^{\mathrm{h}}$ & $14^{\mathrm{g}}$ & $13^{\text {bcd }}$ & $14^{\mathrm{d}}$ & $12^{\mathrm{cd}}$ & $16^{\mathrm{abc}}$ \\
\hline UWCA-05 & $22^{\text {def }}$ & $18^{\mathrm{ef}}$ & $12^{\text {cd }}$ & $16^{\mathrm{cd}}$ & $11^{\mathrm{d}}$ & $15^{\mathrm{abc}}$ \\
\hline UWCA-08 & $18^{\mathrm{g}}$ & $16^{\mathrm{tg}}$ & $18^{\mathrm{ab}}$ & $18^{\mathrm{cd}}$ & $12^{\mathrm{cd}}$ & $19^{\mathrm{a}}$ \\
\hline UWCA-10 & $18^{\mathrm{g}}$ & $16^{\mathrm{tg}}$ & $13^{\text {bcd }}$ & $15^{\mathrm{cd}}$ & $09^{d}$ & $18^{\mathrm{ab}}$ \\
\hline
\end{tabular}

Note: Mean values followed by the superscript letter in each column do not differ significantly at $\mathrm{P}=0.05$ level grouped by DMRT

UWCB: Bacterial isolates, UWCF: fungal isolates, UWCA: actinobacterial isolates

Table.4 Carbon and nitrogen mineralization by efficient urban solid waste degrading microorganisms

\begin{tabular}{|c|c|c|c|c|c|c|c|c|c|}
\hline \multirow[t]{3}{*}{ Isolates } & \multicolumn{9}{|c|}{ Days after degradation } \\
\hline & \multicolumn{3}{|c|}{10} & \multicolumn{3}{|c|}{20} & \multicolumn{3}{|c|}{30} \\
\hline & OC \% & N \% & $C: N$ & OC \% & $\mathbf{N} \%$ & $C: N$ & OC \% & $\mathbf{N} \%$ & C:N \% \\
\hline UWCB-16 & $380.8^{\mathrm{e}}$ & 1.33 & $286.32^{\mathrm{c}}$ & $253.7^{\mathrm{c}}$ & $1.41^{\mathrm{h}}$ & $179.93^{\mathrm{a}}$ & $194.12^{\mathrm{b}}$ & $1.56^{\mathrm{t}}$ & $124.44^{\mathrm{a}}$ \\
\hline UWCB-25 & $372.2^{f}$ & 1.36 & $273.68^{\mathrm{e}}$ & $254.1^{\text {ef }}$ & $1.43^{\mathrm{g}}$ & $177.69^{b}$ & $184.23^{\mathrm{f}}$ & $1.61^{\mathrm{e}}$ & $114.18^{c}$ \\
\hline UWCB-29 & $387.5^{\mathrm{b}}$ & 1.33 & $291.35^{b}$ & $262.12^{\mathrm{a}}$ & $1.46^{\mathrm{f}}$ & $179.53^{\mathrm{ab}}$ & $196.25^{\mathrm{a}}$ & $1.65^{\mathrm{d}}$ & $118.94^{b}$ \\
\hline UWCB-34 & $381.4^{\mathrm{de}}$ & 1.30 & $293.38^{b}$ & $256.5^{\mathrm{d}}$ & $1.48^{\mathrm{de}}$ & $173.31^{\mathrm{c}}$ & $186.12^{\text {de }}$ & $1.63^{\mathrm{f}}$ & $114.42^{b}$ \\
\hline UWCF-02 & $357.2^{i}$ & 1.37 & $260.73^{f}$ & $241.01^{\mathrm{h}}$ & $1.50 \mathrm{~d}^{\mathrm{e}}$ & $160.67^{d}$ & $180.8^{\mathrm{g}}$ & $1.66^{\mathrm{c}}$ & $108.22^{d}$ \\
\hline UWCF-06 & $345.4^{j}$ & 1.39 & $248.49^{\mathrm{g}}$ & $223.15^{j}$ & $1.52^{\mathrm{c}}$ & $146.81^{\mathrm{e}}$ & $178.12^{\mathrm{h}}$ & $1.67^{\mathrm{c}}$ & $108.66^{\mathrm{e}}$ \\
\hline UWCF-07 & $366.6^{\mathrm{g}}$ & 1.30 & $282.0^{c}$ & $257.11^{\mathrm{h}}$ & $1.57^{\mathrm{a}}$ & $163.76^{\mathrm{e}}$ & $182.25^{\mathrm{g}}$ & $1.68^{\mathrm{b}}$ & $106.48^{\mathrm{d}}$ \\
\hline UWCF-09 & $362.5^{\mathrm{h}}$ & 1.30 & $278.85^{d}$ & $254.13^{\mathrm{i}}$ & $1.54^{\mathrm{b}}$ & $165.01^{\mathrm{e}}$ & $179.65^{\mathrm{g}}$ & $1.66^{\mathrm{d}}$ & $107.91^{\mathrm{d}}$ \\
\hline UWCA-03 & $383.3^{\mathrm{c}}$ & 1.36 & $281.84^{c}$ & $260.3 \mathrm{~d}^{\mathrm{e}}$ & $1.48^{\mathrm{d}}$ & $175.88^{\mathrm{c}}$ & $188.35^{\mathrm{c}}$ & $1.67^{\mathrm{b}}$ & $112.78^{\mathrm{c}}$ \\
\hline UWCA-05 & $381.8^{\mathrm{e}}$ & 1.39 & $274.68^{\mathrm{e}}$ & $250.5^{\mathrm{g}}$ & $1.51^{\mathrm{c}}$ & $165.89^{d}$ & $186.57^{\mathrm{t}}$ & $1.67^{\mathrm{a}}$ & $111.72^{d}$ \\
\hline UWCA-08 & $391.8^{\mathrm{a}}$ & 1.32 & $296.82^{\mathrm{a}}$ & $262.0^{\mathrm{b}}$ & $1.50^{\mathrm{d}}$ & $174.67^{\mathrm{c}}$ & $188.37^{\mathrm{d}}$ & $1.62^{\mathrm{e}}$ & $116.28^{\mathrm{a}}$ \\
\hline UWCA-10 & $384.4^{\text {cd }}$ & 1.28 & $300.31 \mathrm{~s}^{\mathrm{a}}$ & $254.5^{\mathrm{t}}$ & $1.47^{\mathrm{ef}}$ & $173.13^{\mathrm{c}}$ & $187.45^{\text {et }}$ & $1.65^{\mathrm{cd}}$ & $113.61^{\mathrm{c}}$ \\
\hline
\end{tabular}

Note: Mean values followed by the superscript letter in each column do not differ significantly at $\mathrm{P}=0.05$ level by DMRT

UWCB: Bacterial isolates, UWCF: fungal isolates, UWCA: actinobacterial isolates 
Table.5 Molecular characterization of selected efficient urban solid waste degrading microorganisms for consortium preparation

\begin{tabular}{|c|c|c|c|}
\hline Sl. No. & \multicolumn{2}{|c|}{$\begin{array}{c}\text { Urban solid waste degrading } \\
\text { microorganisms }\end{array}$} & Identification \\
\hline $\mathbf{1}$ & Fungal Isolates & UWCF-09 & Trichoderma harzianum \\
\cline { 1 - 2 } $\mathbf{2}$ & & UWCF-07 & Penicillium polonicum \\
\hline $\mathbf{3}$ & & UWCF-02 & Coprinus spp \\
\hline $\mathbf{4}$ & Bacteria & UWCB-34 & Bacillus cereus \\
\hline $\mathbf{5}$ & & UWCB-25 & Bacillus licheniformis \\
\hline $\mathbf{6}$ & Actinobacteria & UWCA-05 & Streptomyces albus \\
\hline
\end{tabular}

Bacterial isolate UWCB-34 (26 mm) showed highest pectinase producing ability followed by fungal isolate UWCF-07 $(24 \mathrm{~mm})$ which was significantly different from all other isolates. Protease production and starch hydrolysis was found highest in bacterial isolate UWCB-25 (20 mm) and UWCB-34 (23 $\mathrm{mm}$ ) compared to all the other isolates among the organisms.

Ligninase production ability was found highest in the fungal isolates UWCF-02, 07 and $09(22 \mathrm{~mm})$ compared to all the bacterial and actinobacterial isolates which was statistically significant among the different isolates, whereas chitinase producing efficiency was found highest in the bacterial isolate UWCB-25 (19 $\mathrm{mm})$ and in actinobacterial isolate UWCA-08 (19 mm) followed by UWCA-10 (18 mm) compared to all the other isolates. Previous work showed twenty four isolates of Trichoderma which were screened for $\beta$-1, 3-glucanase and chitinase activity. Out of these organisms, a strain identified as Trichoderma harzianum secreted the highest chitinases and $\beta-1,3-$ glucanases (El-Katatny et al., 2000).

Carbon and nitrogen mineralization of urban solid waste with saw dust

The results on the changes in per cent $\mathrm{OC}$, per cent nitrogen and $\mathrm{C}: \mathrm{N}$ during decomposition of sawdust along urban solid waste residues is presented in Table 4. Among the isolated organisms, the fungal isolate UWCF-07 showed highest mineralization ability of carbon and nitrogen followed by bacterial isolate UWCB-25 and actinobacteria isolate UWCA-05 throughout the period of urban solid waste degradation. Statistically significant decrease in $\mathrm{C}$ : $\mathrm{N}$ was obtained in the treatment inoculated with the fungal isolate UWCF-06 (108.66) compared to all the other isolated organisms. In general, there was significant increase in per cent $\mathrm{N}$ and decrease in per cent $\mathrm{OC}$ and $\mathrm{C}$ : $\mathrm{N}$ was observed throughout the decomposition. At $30^{\text {th }}$ day of decomposition, among the bacterial isolates UWCB-25 recorded highest mineralization ability of carbon and nitrogen, which was found to reduce highest $\mathrm{C}: \mathrm{N}$ of 114.18 followed by UWCB-34 (114.42) whereas among the actinobacterial isolates UWCA-05 (111.72) recorded highest reduction of $\mathrm{C}: \mathrm{N}$ followed by UWCA-03 (112.78). But the highest efficiency of mineralization of carbon and nitrogen was found in fungal isolates UWCF-07, UWCF-09 and UWCF-02 (106.48, 107.91 and 108.22 of $\mathrm{C}: \mathrm{N}$ respectively) compared to all the other isolated organisms during decomposition of sawdust with urban solid waste. This might be due to break down of complex OC molecules to easily degrading molecules by the activity of microorganism over a period of decomposition process. As a result, carbon content in the raw material was higher in the beginning of the composting and 
reduces considerably during the decomposition (Abdullah et al., 2018). These results are in agreement with the findings of Shersing et al., (2016) who reported that kitchen waste is rich in nitrogen which helps in enhancing the nitrogen content in decomposed material which in turn helps in reducing the $\mathrm{C}: \mathrm{N}$ ratio.

\section{Selection of microbial isolates for the development of consortium}

Among twelve microbial cultures screened, six cultures were selected to form the consortium based on their ability to produce of enzymes and carbon and nitrogen mineralization efficiency. Further the selected isolates for development of consortium comprised two bacterial and one actinobacterial isolate characterized by partial sequencing of $16 \mathrm{~S}$ ribosomal RNA with three fungal isolates characterized with partial $18 \mathrm{~S}$ rRNA gene, 5.8S rRNA gene sequencing of ITS1 and ITS4 (Table 5). From the above mentioned studies, it was concluded that fungi were more efficient in enzyme production, carbon and nitrogen mineralization than the bacterial and actinobacterial isolates. Kumar et al., (2008) developed a fungal consortium consisting of Aspergillus nidulans, Scytalidium thermophilus and Humicola species to compost paddy straw and found it effective in converting paddy straw into nutritionally rich compost, thereby leading to economical and environment friendly disposal of crop residue.

Since no single organism will be able to produce all the enzymes necessary for the degradation of all types of organic waste materials, there is a need to use a consortium of microorganisms which can act synergistically for the rapid conversion of different organic waste materials present in urban solid waste. Based on their ability to produce enzymes, carbon and nitrogen mineralization efficiency with sawdust, microbial consortium was formed comprising three fungi (Trichoderma harzianum, Penicillium polonicum and Coprinus sp.), two bacterial isolates (Bacillus licheniformis and Bacillus cereus) and one actinobacterial isolate (Streptomyces albus) which could be utilized for hastening the process of urban solid waste and production of enriched organic manure for sustainable production of agriculture.

\section{References}

Abdullah, A., Basaleh., Muhammad, H. and Al-Malack., 2018, Utilization of municipal organic solid waste for production of activated carbon in Saudi Arabia. Arab. J. Sci. Engg., 47(7): 3585-3599.

Anonymous, 1957, Manual of microbiological method. McGraw Hill Book Company Inc., New York, pp. 127.

Barthalomew, J. W. and Mittewer, J., 1950, A simplified bacterial strain. Stain Tech., 25: 153 .

Cappuccino, J. G. and Sherman, N., 1992, Microbiology: A laboratory manual. The Benjamin/ Comings Publishing Company, Inc., California.

Channabasavanna, A. S. and Abdul Rahaman, A. S., 2002 Utilization of municipal waste in Agriculture, Kissan World, March: 38-39.

Chethan Kumar, 2017, Garbage nation? $70 \%$ of urban solid waste dumped unscientifically, Times of India. $8^{\text {th }}$ Feb. page: 8.

El-Katatny, M. H., Somitsch, W., Robra, K. H., El-Katatny, M. S and Gübitz, G. M. 2000, Production of chitinase and $\beta$-1,3-glucanase by Trichoderma harzianum for control of the phytopathogenic fungus Sclerotium rolfsii, Food Technol. Biotechnol., 38 (3): 173-180. 
Heckman, J., 2006, A History Of Organic Farming: Transitions From Sir. Albert Howard's War in The Soil To USDA National Organic program For Renewable, Agricultural Food System. 21: $143-150$.

Joshi, R. and Ahamed, S., 2016, Environmental chemistry, pollution and waste management. Environ. Sci., 2: $1-18$.

Kumar, A., Gaind, S. and Nain, L., 2008, Evaluation of thermophilic fungal consortium for paddy straw composting. Biodegradation, 19: 395402.

Macdonald, D. M. G. C. and Griffin, S. E., 1981, Returning wastes to the land. Report of the advisory committee on technology for international development commission on international relations. National Research Council, National Academy Press, Washington, DC.

Piper, C. S., 1966, Soil and plant analyses. Hans Pub. Bombay.

Saha, A., Subhas Chandra. and Santra., 2014, Isolation and characterization of bacteria isolated form municipal solid waste for production of industrial enzymes and waste degradation. $J$. Microbiol. Expertn. 1(1):12-19.

Saud Jawahar. S., 2013, Solid Waste Management Utilizing Microbial
Consortia and its Comparative Effectiveness Study With the Vermicompost Internl. J. Engg. Res.Tech., 2 (10): 2270-2285.

Sharma, S., Shah, K. W., 2005, Generation and disposal of solid waste in Hoshangabad. In:Book of Proceedings of the Second International Congress of Chemistry and environment, Indore, India, pp. 749-751.

Sher Singh, G., Archana, S. and Asha Mukul, J., 2016., Isolation and Identification of protease producing bacteria through biodegradation of protein content of kitchen wastes in Gwalior, India., Int. J. Curr. Microbiol. APP. Sci., 5(10): 204-211.

Tiquia, S. M. and Tam, N. F. Y., 2000, Cocomposting of spent pig litter and sludge with forced-aeration. Biores. Technol. 72: 1-7.

Walkley, A. and Black, C. A., 1934, Method for determining soil organic matter and proposed modification of the chromic acid titration method. Soil Sci., 37: 2938.

Zaved, H. K., Mizanur Rahaman, M., Mashair Rahamn, Atiqur Rahaman, Arafat, S. M. Y. and Safiur Rahaman., 2018, Isolation and Characterization of effective bacteria for solid waste degradation for organic manure. Sci. Tech. J. 8(2): 44-55.

\section{How to cite this article:}

Davalsab Javoor and Narayanaswamy, B. 2021. Evaluation of Microbial Consortium for the Rapid Composting of Urban Solid Waste. Int.J.Curr.Microbiol.App.Sci. 10(04): 287-296. doi: https://doi.org/10.20546/ijcmas.2021.1004.029 